\title{
Immature Extragonadal Teratoma
}

National Cancer Institute

\section{Source}

National Cancer Institute. Immature Extragonadal Teratoma. NCI Thesaurus. Code C8884.

An immature teratoma that develops as a primary tumor in an anatomic site other than the testis or ovary. 